\title{
The US-China Trade War and what about it
}

\author{
Yawei Li \\ Emma Willard, 285 Pawling Avenue, Troy, NY 12180. \\ leanna_lyw@163.com
}

The relationship between the United States and China dates back to the nineteenth century. In the more than one-hundred years they have been interacting with one another, their respective policies and strategies have undergone a variety of changes. Recently, one significant event has occurred between the two nations, the trade war. This economic conflict began in 2018 when the U.S. imposed tariffs on Chinese products. Still ongoing, the trade war has a negative impact on both nations. Although it is called the trade war, the conflict between the two nations is not restricted in the area of trading. In fact, at the center of the trade war, lies the matter of technological development, which represent a point of anxiety for the United States. As China continues to develop its ability to produce technological products, its importance in the world will shift from a manufacturing center to a center of strategic complexity. As the tension mounts, the there are many options available to both states to deescalate, each of which will come with a consequence. Because they are the two largest economies, the outcome of this war will not merely impact these two countries, but will reverberate worldwide.

The relationship between China and the United States has a long and complicated history. One of the most significant events is the Treaty of Wanghia, which was signed between the two nations in 1844. Known also as the "Treaty of peace, amity, and commerce, between the United States of America and the Chinese Empire," this unequal agreement gave the U.S. more privileges in trading than Britain in China. In addition to being the first treaty signed between the U.S. and China, the agreement is important because it established a precedent for how the two countries would understand economic relations. The treaty contained more than 30 articles about the U.S.-China relationship and demands for the Chinese government. These demands included restrictions on China's ability to alter tariff levels unilaterally. Additionally, the treaty maintained that disputes between the two nations would be adjudicated under American law. While trade has been an important point of both connection and controversy between the two countries, there have been other aspects of the relationship that have historical precedent, one of which is the question of immigration. The Chinese Exclusion Act, which barred Chinese from immigrating to the U.S., clearly demonstrates the strain of prejudice toward China that developed in the late nineteenth century. In 1972, the visit of president Nixon to China represents the two countries moving toward rapprochement, marking the beginning of Chinese-US partner relationship on trading, military, and so on.

Since their interaction began, China has been subject to the desire of western nations to impose their rules and norms. This imposition has applied not only to trading, but other areas of social and political life as well, including human rights. The west has consistently maintained that China must adhere to its standards of human rights. However, the concept itself is not native to China. From a Chinese perspective, human rights are a general and vague concept that depends not on universal laws but rather on cultural attitudes that are specific to individual societies. Thus, different countries have different methods and concerns when dealing with events related to the rights of their citizens. Even though there are clear cultural difference between the U.S. and China, the U.S. has consistently pressured China to conform and has punished China when it has failed to deal with human rights as the west desires. 
Besides the topic of human rights, China's international trade is also restricted by western rules. In other words, China must adhere to western rules if it wishes to be part of the community of trading nations. For instance, in order to participate in the global economy, China has been required to join the global trade organization, WTO, which was founded by mainly European countries and the U.S. Although China does not always abide by rulings of the WTO, it nonetheless maintains membership and does follow most practices in order to facilitate trade with different countries because other countries are also under the western system. Even though China has been pressured by the United States, the relationship between these two countries has changed over time, especially as China has developed greater economic strength, allowing it to be more assertive. After the Chinese civil war, which ended in 1949, China did not have a very influential power at the international level. In 2001 , when China entered the WTO and became its 143rd member, it was the sixth-largest economy in the world with GDP 1.3 trillion. At the same time, America was the largest global economy with GDP 10.6 trillion. After 17 years, China is now the second-largest economy with GDP 13.6 trillion, and the US still remains the first with GDP 20.4 trillion. China's economy is still under a rapid growth and predictions are made by experts that China's GDP will surpass the U.S.'s in the future. The bulk of China's economic growth has taken place through manufacturing. Recently, however, this is beginning to shift, as China has developed its technological center. The report of IPlytic, who is leading the 5G patent race, shows the Chinese company Huawei owns the most $5 \mathrm{G}$ patents compared to other companies from all over the world. The leading of Huawei in $5 \mathrm{G}$ patents is a visible sign for the US and the world that China is changing from a technological processor to a producer.

The change in economic focus is largely responsible for the recent and trade between China and the US. In 2017, China was the biggest merchandise import market for the U.S. At that time, the U.S. imported products worth $\$ 506$ billion from China. The U.S. and China are the largest trading partners in the world with total trade value 659.8 billion in. According to the Treasury Department, way back in 2007 the U.S. products exported to China increased by 187 percent since 2001, while exporting to the world only grew 38 percent. Given these figures, it is clear that the U.S.-China trade relationship is mutually beneficial. It is very influential not only for both countries, but also for the whole world because the wealth created through this partnership supports the development and maintenance of other economies. Even though there are downsides in this relationship, the profits exceed the disadvantages. China exports manufacturing goods, such as computer accessories, to the U.S. and imports high-value products, such as aerospace parts and vehicles. These two countries trade to meet their needs for products that they demand the most. One result of the increased presence of China as a manufacturing and assembly center for U.S. goods has been the loss of low-paying manufacturing jobs in the U.S. However, exporting high-tech goods to China creates new jobs that makes up for the displacement of American workers. For example, in 2015, exports to China provided 1.8 million new American jobs. The U.S. sells high-valued and technological products to China, and China mainly exports manufacturing goods to the U.S.

In its negotiations with China, the U.S. has employed different methods. However, the U.S. has never faced a country like China, who has the potential to surpass it. In March 2018, after years of pursuing a different strategy, the U.S. decided to start confronting China directly. The trade war that the Trump administration initiated attempted to eliminate the threat from China. The trade war involves the two world biggest economies fighting about manufacturing, trade, technology, and the future of the global financial arrangement. It is the battle and a chance for them to change the current situation, the countries' futures depend on the decision they are making. The two countries can change completely from what they are in the beginning.

On March $1^{\text {st }}, 2018$, The U.S. government posed tariffs on steel and aluminum products imported from all over the world, with exception of imports from Mexico and Canada, which foreshadowed the start of the trade war. At the same time, the U.S. increased its imports of steel and aluminum from Canada and Mexico. This action is not only harmful for China, but also for the U.S.'s other allies. This step the U.S. took pushes its allies away, providing 
them with a chance to cooperate with other countries, such as China, which opposes its purpose for triggering a trade war. Even though the U.S. later exempted the European Union, Australia, and other countries, the initial tariffs produced some distrust between the U.S. and its allies. In effect, the American decision reminded its allies that they are very dependent on the U.S. and can be damaged by its economic decisions.

On March 22nd, the U.S. planned to impose tariffs on Chinese products, accusing China of stealing American technology. The tariffs were meant as punishment for unequal trade practices on the part of China. With this act of reprisal, the trade war began. On March $27^{\text {th }}$, the Trump administration released the Section 301 Investigation on China. In response, on April $2^{\text {nd }}$ and $4^{\text {th }}$, the Chinese authorities stated that they would place tariffs on U.S. products and 25\% taxes on imports of 2016, including soybeans, fresh fruits, wine, auto mobiles, and more. A few days later, on August 7th, both countries imposed 25\% tariff on $\$ 16$ billion products. After this point, the U.S. imposed tariff on Chinese products worth billions of dollars a few times, and China responded with offering to buy more U.S. products if the imposed tax impose were rescinded.

At the same time that the U.S. was targeting Chinese products, it began to address Chinese technological companies. Since April 2018, the U.S. has accused ZTE as well as Huawei of threatening national security and of trying to obtain the U.S.'s technologies. As a result, the U.S. banned these companies from the U.S. market. China is at the stage of transforming to produce technological products itself, which can be seen from the invention of 5G. The Chinese technological companies, such as Huawei, are involved in this transition in a large part because they are one of the key factors affecting Chinese technological development. At the same time, these companies have been added to the Entity List by the government. The two nations are accusing each other of taking the wrong actions. What this confrontation reveals is that the largest point of contention between the U.S. and China is the struggle to dominate the emerging technological space that 5G provides. While the U.S. has previously been content to allow China to operate as a purely manufacturing center, it is anxious about the implications of Chinese increased technological ability. The decisions made by China and the US are not only affecting themselves, but also the economy for the whole world.

On 14th June 2019, the Chinese Ambassador, Jianmin Zhang, stated that "the U.S. has kept taking unilateral and protectionist measures and practiced economic hegemony. To safeguard our national interests, we cannot but respond with forceful measures". As this speech makes clear, China views the U.S. as an imperialist power that is attempting to assert its hegemonic authority. According to Chinese foreign ministry spokesman, Chunyin Hua, "China will take necessary countermeasures to firmly safeguard our just and legitimate rights and interests". From their speeches, it is shown that China is ready and not afraid to resist the U.S. for the nation's interest if the trade war continues.

The situation changed after Trump attended the G20 held in Japan. At that time, Trump said that "I promised that for at least the time being we're not going to be lifting tariffs on China. We won't be adding an additional tremendous amount". This ceasefire on tariffs did not mark the end of the trade war, and the tension between the two nations continues to increase.

The trade war is not yet stopped, which can be revealed by the arm sale between the US and Taiwan. Although this seems to be irrelevant to the topic of economy the trade war, the relationship between the US and Taiwan has always been a significant part of the US-China relationship. Before the US and China started the formal relationship in 1979, the US sold weapons to Taiwan directly. However, when this relationship was formed, China asked the US to quit the arm deals and connection with Taiwan. When agreements were made between the two sides, The US passed the Taiwan Relation Act, which the US would assist Taiwan only if it is attacked by mainland China, and it ended the formal relation with Taiwan. However, the US recently has approved an arm sale to Taiwan, which worth 2 billion dollars. In response to this action, on July 12th, 2019, the Chinese 
Foreign Minister Wang Yi stated that "the Taiwan question is purely China's internal affairs and allows no outside interference. No one or any force can stop the historical process of reunification between the two sides across the Taiwan Strait, nor should they underestimate the firm will of the Chinese government and people in safeguarding national sovereignty and territorial integrity". His response indicates China's discontent with the US interferes in China's own affairs, particularly at the special time, which the relationship between the two nations is disharmonious.

The decisions that the U.S. and China are going to make about the trade war will severely affect the relation and conditions of the two countries. The actions that the U.S. take would affect China's reactions and responses because the U.S. is the dominant power in this relation until now. Looking at the current situation, there are many options that the U.S. could take. The present confrontational attitude toward China is the outgrowth of the administration's realist agenda. Realism means that every country is an individual within the competition and each country needs to be prepared to compete with others in order to survive. From the perspective of realists, the world is in the state of anarchy; every country is developing its military and economy, which are driven by their own interests and desire of power. People who believe in this theory does not agree with cooperation among different countries and do not support the existence of international organizations for determining the behavior of nation states. In the idea of Realism, every country is an opponent of other nations. In terms of this theory, the U.S. is most concerned about its benefits and power, without considering the profits and relationship with other countries. The U.S. views the relationships with other countries as competitions. The growth of certain major countries, which can become a potential threat to the status of the U.S., makes the U.S. feels insecure. As China has developed rapidly, the U.S. desire to limit its growth has resulted in the trade war, which has been undertaken to secure American dominance, which the US feels its position is threatened by China. China and the U.S. are dependent trade partners for each other so far. Continuing the trade war, in other words the competition, would not be a beneficial and effective resolution for either side. Even if the U.S. contains China's economy and technology through its aggressive and confrontational policies, the damage will be bilateral because it will hurt the U.S. as well. Additionally, confrontation will create harm for both sides in terms of the reports that the Chinese diplomats made. China is not afraid to fight back if the U.S. does not stop the trade war. Then a vicious cycle would form: the U.S. increases tariff on Chinese products and China does the same in return and both countries ban things from each other, or even worse than only having war on trading. Therefore, realism might not be the best solution to continue with under this condition. Other than realism, there are other options the US and China can take.

Confrontation is the other strategy that the U.S. could adopt when dealing with China. Rather than turn to a set of policies based on the realist assumptions about global relations, the U.S. could instead adopt strategic principles that are rooted in Liberalism, a separate theory that depends not on conflict but on cooperation and the promotion of shared values. Liberalism is almost the opposite of Realism. It represents the ideas of democracy and collaborations between different countries. The concept appears in John Locke's Two Treatises of Government, which helped to develop the modern definition and belief of Liberalism. In this worldview, international relations are not defined by individual countries and their pursuit of survival. It is more about maintaining the characteristic of each country and the rights of people accessing to freedom and property. Liberalists believe there is a global goal for each country and there should not have war between the countries. Compared to Realism, Liberalists acknowledge the existence of third organizations and global rules to maintain the order of the society. Thus, every country is under a certain type of international rules to restrain their decisions. Based on the present U.S.-China relationship, it is hard to achieve Liberalism because the two nations are opposing each other right now. Neither of the two nations would likely to change only their own policies 
to meet the requirement of the other and become partners shortly, even though China and the U.S. are still under several global organizations. Nevertheless, the U.S. could more actively adopt or pursue policies that are designed to promote greater freedom and democracy in China. If such a shift could be produced, it would yield results that nullified the need for an aggressive trade war.

Other than Liberalism, accommodation is also one of the options. Of the three proposed options, I argue that the U.S. should adopt this strategy. Accommodation is somewhere in the middle between Realism and Liberalism. Accommodation neither requires the U.S. to compete with China nor cooperate with China. This method would not shift the U.S.-China relationship from confrontation immediately to collaboration, which takes a long time. Having accommodation policy means the U.S. would put China on the same position as itself. In other words, it would view China as an equal. The U.S. would accept and acknowledge the decisions that China makes. Under this policy, the U.S. would not seek to reform the Chinese structure. Instead, it would allow China to have its own sphere of influence. However, it is not only about U.S. accommodating China; at the same time, China would have to accept the American position as equally valid. The cause of trade war is not one-sided, so it would be better if the two nations reflect on their own weaknesses, rather than focusing on blaming each other for creating problems.

\section{REFERENCES}

(2019, June 20). Ambassador Zhang Jianmin on China-US Trade Dispute. Retrieved from https://usa.chinadaily. com.cn/a/201906/20/WS5d0a60cba3103dbf143292fc.html

Liptak, K. (2019, June 29). Trump says trade talks 'back on track' after meeting China's Xi. Retrieved from https://edition.cnn.com/2019/06/28/politics/trade-donald-trump-xi-jinping-g20/index.html

(2019, August 20). List of countries by GDP (nominal). Retrieved from https://en.wikipedia.org/wiki/List_of_ countries_by_GDP_(nominal)

Lumbers, M. (2015, July 10). Whither the Pivot? Alternative U.S. Strategies for Responding to China's Rise. Retrieved from https://tandfonline.com/doi/abs/10.1080/01495933.2015.1069510?src=recsys\&journa lCode $=$ ucst 20

Moyer, L. (2018, April 4). A timeline of Trump's escalating trade war with the world. Retrieved from https:// www.cnbc.com/2018/04/04/a-timeline-of-president-trumps-escalating-trade-war-with-the-world.html

(n.d.). The People's Republic of China. Retrieved from https://ustr.gov/countries-regions/china-mongoliataiwan/peoples-republic-china

(1901, December 13). Treaty of Wangxia (Treaty of Wang-hsia), May 18, 1844. Retrieved from https://china. usc.edu/treaty-wangxia-treaty-wang-hsia-may-18-1844

(n.d.). The People's Republic of China. Retrieved from https://ustr.gov/countries-regions/china-mongoliataiwan/peoples-republic-china

(2007, May 24). U.S. Department of the Treasury. Retrieved from https://www.treasury.gov/press-center/ press-releases/Pages/hp423.aspx

(2018, January 26). Understanding the US-China Trade Relationship. Retrieved from https://www.uschina. org/reports/understanding-us-china-trade-relationship

(n.d.). U.S.-China Relations Since 1949: Asia for Educators: Columbia University. Retrieved from http://afe. easia.columbia.edu/special/china_1950_us_china.htm 
The US-China Trade War and what about it

(2018, July 11). Trade war 'fight between protectionism and free trade': FM. Retrieved from http://www. chinadaily.com.cn/a/201807/11/WS5b45f2f5a310796df4df5d7c.html

(2019, July 12). Wang Yi: Those Who Play with Fire on the Taiwan-related Issues Will Lift a Rock only to Drop it on Their Own Feet. Retrieved from https://www.mfa.gov.cn/ce/cese/eng/wjdt/t1681344.htm

(2019, July). Who is leading the $5 \mathrm{G}$ patent race? - iplytics.com. Retrieved from https://www.iplytics.com/wpcontent/uploads/2019/01/Who-Leads-the-5G-Patent-Race_2019.pdf

Citation: Yawei Li, "The US-China Trade War and what about it". American Research Journal of History and Culture, vol 5, no. 1; pp: 1-6.

Copyright (c) 2019 Yawei Li. This is an open access article distributed under the Creative Commons Attribution License, which permits unrestricted use, distribution, and reproduction in any medium, provided the original work is properly cited. 